\title{
The Role of Teachers in Fostering Religious Multiculturalism
}

\author{
Emiliati Ulfa ${ }^{1}$; Dedi Djubaedi ${ }^{2}$; Cecep Sumarna ${ }^{2}$; Siti Fatimah ${ }^{3}$; Suklani $^{3}$; Abas Hidayat ${ }^{4}$ \\ ${ }^{1}$ Doctoral Student, Institut Agama Islam Negeri Syekh Nurjati, Cirebon, Indonesia \\ ${ }^{2}$ Professor, Institut Agama Islam Negeri Syekh Nurjati, Cirebon, Indonesia \\ ${ }^{3}$ Lecturer, Institut Agama Islam Negeri Syekh Nurjati, Cirebon, Indonesia
}

${ }^{4}$ Lecturer, Sekolah Tinggi Ilmu Kesehatan Cirebon, Indonesia. Doctoral Student, Institut Agama Islam Negeri Syekh Nurjati, Cirebon, Indonesia

http://dx.doi.org/10.18415/ijmmu.v8i10.3065

\begin{abstract}
Conflicts that occur in the school environment as the dynamics of a multicultural society. Shaping the character of students' multicultural education is the main responsibility of a teacher. The objectives of the study are 1) To find and explain the role of Islamic Religious Education teachers in fostering religious attitudes in multicultural society in schools; 2) To find, understand, and explain the strategy of Islamic Education teachers in implementing multicultural values in schools; 3) To find, understand, and explain what are the obstacles faced by Islamic Religious Education teachers in implementing multicultural education in schools. This research is qualitative descriptive analysis with depth interview method. Data were obtained from interviews with 25 teachers from various subject areas at Cirebon 2 State High School, West Java, Indonesia. The positive role of the teacher can be seen in the attitude of fostering religious awareness and multicultural attitudes in schools by providing religious lessons. The strategy of Islamic religious education teachers in growing religious multiculturalism through sustainable character education learning. The obstacles faced by some education teachers are religious fanaticism, teachers cannot control the implementation of daily interactions and different levels of student awareness.
\end{abstract}

Keywords: Multicultural; Islamic Education; Religious; Teachers; Role

\section{Introduction}

Serious issues that have been the subject of international studies in recent years are radicalism, terrorism and racial discrimination (Pratama et al., 2021). Radicals must review their attitudes towards multiculturalism (Modood, 2009). Multicultural education has an important role in eradicating the causes of terrorism (Cunningham, 2005). Multiculturalism is not a means for racism, but as a means to prevent racism (De Ricco \& Sciarra, 2005). The cause of these issues is the gap in the understanding of multicultural in society. One part of multiculturalism is religious diversity (Carlan et al., 2021). Therefore, fostering a good multicultural religion is one of the efforts to prevent the emergence of radicalism, terrorism and racism. 
Diversity, one of which is that religion brings wisdom, on the other hand it can be a factor that causes conflict in society. Religious pluralism is a challenge that people face today (Naim, 2017). Indonesia is a country that has a large number of Muslims. Therefore, Muslims have a big task in the future to work together with other religious communities, to set an example of accepting with all their hearts about tolerance, respecting pluralism, because pluralism is an undeniable fact. In Indonesian society, there are still groups who show intolerance and view pluralism as a threat to the nation. This group's view is that religion is no longer a blessing, but has turned into a curse and a coercive doctrine(Usman et al., 2014).

One of the solutions to prevent the negative impact of multiculturalism is through education. Teachers have an important role in shaping the character of students (Mathison, 1999). Shaping the character of students' multicultural education is the main responsibility of a teacher (Y1lmaz, 2016). Conflicts that occur in the school environment as the dynamics of a multicultural society (Akob, 2016).

In Indonesia, there are many cases of brawls between students, due to the lack of understanding of multicultural education. Therefore, Islamic Religious Education must be a guide for students to live in harmony, peace, and mutual respect for one another. Islam as rahmatan lil'alamin which means tenderness and compassion or in other words Allah gives mercy to all his creatures. Rahmatan lil'alamin as a guide for the life of the nation, state and society. Students and teachers from various religions are God's creations who are given different beliefs of each. Muslims should not have the ambition to force others to follow what we profess and believe in. All humans can become successful humans with the beliefs they hold.

The role of the teacher is very important. Therefore, the objectives of the study are 1) To find and explain the role of Islamic Religious Education teachers in fostering religious attitudes in multicultural society in schools; 2) To find, understand, and explain the strategy of Islamic Education teachers in implementing multicultural values in schools; 3) To find, understand, and explain what are the obstacles faced by Islamic Religious Education teachers in implementing multicultural education in schools.

\section{Method}

This research is qualitative descriptive analysis with depth interview method. Data were obtained from interviews with Islamic religious education teachers, principals, vice principals, civics education teachers, history teachers, counseling guidance teachers and homeroom teachers and students at Cirebon 2 State High School, West Java, Indonesia. A total of 25 teachers from various subject areas.

\section{Demographic Diversity of Cirebon 2 State High School}

The city of Cirebon is an area located in a coastal area, its name is familiar to the public because it is known as the City of Wali, which means that it does not escape the spread of Islam in Java, Indonesia. Cirebon is also known as a diverse area ranging from ethnicity, race, religion, culture and dialects of various languages. The value of diversity in Cirebon is very broad because all religions are included in it, starting from Islam, Christianity, Catholicism, Buddhism, Confucianism and other faiths. The people of Cirebon come from Javanese, Sundanese, Arabic, Chinese, and many others. The word Cirebon comes from the word Caruban or Syaruban which means mixing (Juwono et al., 2017).

The diversity in Cirebon can be seen from the number of adherents of the Islamic religion, which is 316,576 people. There are 14,601 adherents of the Catholic Christian religion. There are 6,738 followers of Protestant Christianity. There are 109 Buddhists. There are 2,275 adherents of Hinduism. 62 adherents of the Confucian religion. Adherents of other faiths 6 people. (https://data.cirebonkota.go.id/).

One of the multicultural schools in Cirebon is the Cirebon 2 State High School. At this school once had one Christian teacher, non-Muslim religious activities were arranged and fostered by the teacher. At 
this time (2021), the teachers at the Cirebon 2 State High School are all Muslim. So that the learning activities of non-Muslim students are returned to religious activities which are held outside the school environment.

The dispute that had occurred at the Cirebon 2 State High School was related to fanaticism. Fanaticism of one religion makes disputes. However, this matter can be handled and resolved properly. In this regard, the teachers at the Cirebon 2 State High School strive to foster a spirit of tolerance, togetherness, and brotherhood to foster religious multiculturalism in the school environment.

Cirebon 2 State High School applies multicultural values in the learning process. This can be seen from the religious diversity of students, with a total of 1227 students. There are 1195 Muslim students. There are 32 students who are non-Muslim. In every activity in the school, the teacher helps students learn about the differences that exist in the school's students, and cannot be separated from building mutual aspects or cultural values and being open in thinking.

\section{Multicultural Theory}

The fourth president of Indonesia, Dr. K. H. Abdurrahman Wahid or familiarly called Gus Dur, conveyed the discourse regarding the indigenization of Islam. Indigenization of Islam means prioritizing local wisdom which is the need for Islamic laws that are implemented in people's lives, but not ignoring the developing culture and traditions. Support the presence of Islamic culture in a syar'i and aqli law that is not rigid in practices in people's lives. Thus, it is important to put forward the rules of ushul fiqh which states that aladatu muhakamat that a custom is a law (Burhani et al., 2020).

Gus Dur's multicultural concept views that cultural diversity which has a positive connotation can be realized in several aspects, one of which is education. As a figure who is dubbed the Father of PluralismMulticulturalism, he explained that education must vary according to their respective cultures. Diverse education does not deviate from the goal, but is an effort to achieve educational goals in various ways. Gus Dur saw the need for self-confidence from individuals regarding their respective cultures. In this example, he offers a solution which is often called Islamic indigenization, namely how to integrate Islam with local culture, or Islamic education with local education (Setiawan, 2017).

Gusdur's principles of multicultural education are: 1) Multicultural education needs to be political in nature that puts people's justice first in obtaining education; 2) Multicultural education consists of schools and institutions that are integralistic; 3) Multicultural education puts forward reformists; 4) Multicultural education builds confidence in students that it has the potential to be widely developed; 5) multicultural education needs to provide a sense of justice for all students (Burhani et al., 2020; Miskan, 2018; Shohib, 2020).

Indonesia is a country that has many cultures, each culture of Indonesia has its own characteristics. Islamic education in applying multiculturalism in Indonesia as an effort to provide cultural reality that must be upheld. Islamic education in Indonesia as education that prioritizes noble character along with a culture that is built with local wisdom, local wisdom as a very high value of wealth. Gus Dur fought for the values of multiculturalism as a new breakthrough to unite plurality in a heterogeneous and pluralistic society. He is of the opinion that, in order to advance a nation and uphold pluralism in society, it does not only lie in a pattern of peaceful coexistence, but is still open to the emergence of misunderstandings between community groups which at a certain moment can lead to disintegration or disagreement.Therefore, there is a need for multicultural values in education (Miskan, 2018). 


\section{Results and Discussion}

Islamic religious education teachers foster religious multiculturalism in the Cirebon 2 State High School by building an atmosphere of KBM (teaching and learning) in the classroom with harmony between Muslim and non-Muslim students. The role of the teacher when learning in class is one of the keys that can create a harmonious atmosphere with various kinds of activities and learning materials for Islamic religious education in schools.

The results of the survey of the Cirebon 2 State High School placed students randomly in class divisions, so that students could interact with the various differences in the class in a positive way. Communication determines the success of a multicultural project (Ochieng \& Price, 2010). Communication between teachers of Islamic religious education and all students who are harmonious is the key for schools to establish interactions with high tolerance, because of the program of religious activities to commemorate Islamic holidays. Efforts to foster a positive multicultural education between teachers and students aim to reduce the gap. The role of Islamic religious education teachers is an important factor in efforts to foster religious multiculturalism, through an atmosphere of harmony during Islamic religious education learning.

Managerial effectiveness has an influence on multicultural competence (Chrobot-Mason \& Leslie, 2012). Achieving success in growing religious multicultural education must consider the factors that support and manage education. The supporting factor is the planning program because it is a determinant and makes it easier and becomes an implementation guide. Management and design of learning administration are supporting factors for success in growing religious multicultural education at Cirebon 2 State High School.

Learning experiences can train students to be sporty towards the strengths and weaknesses of themselves and others. Students are also trained to be able to appreciate, acknowledge, and take positive things from other students even though they are from minority groups in the class. So that there is a process of transformation and acculturation process between students. It can also train students to be open, positive thinking and big-hearted people, so they are not easy to be prejudiced, accuse, and label other groups.

Based on the results of interviews with 3 Islamic religious education teachers, the principal, vice principals and 20 other teachers regarding the role of Islamic religious education teachers in fostering religious multiculturalism in the Cirebon 2 State High School, it was found:

First, the role of Islamic religious education teachers in cultivating religious multicultural education by presenting learning and packaging the material to be delivered in KBM activities in a creative and interesting way so that students do not get bored when the KBM takes place. Simple but the meaning and lessons that can be taken from Islamic religious education materials can be absorbed and applied by students in the school environment, play environment and home environment. Islamic religious education teachers are the main figures in growing multicultural education in the environment.

Second, the strategy of Islamic religious education teachers as an effort to foster multicultural religious education so that they can strengthen the faith and Islamic beliefs of Muslim students who are struggling and become identity in schools in this era of globalization. In this era of globalization and modernity, the wide open relationship is not only within the Cirebon 2 State High School, but also the relationships that can be reached even though they are different schools, cities and countries. Indonesian culture, which is known as eastern culture, with the majority of its population being Muslim. Having very strong Islamic values related to socializing, speaking, behaving and dressing. In Islam everything is regulated and has been stated in the verses of the Al-Qur'an.

Third, the constraint of the multicultural education value program is how to manage it. Principals and teachers as planners and managers in cultivating religious multicultural education in the Cirebon 2 State 
High School environment. Lack of knowledge of multicultural education teaching techniques is an obstacle. However, if multicultural education training programs are held, it will be easier for teachers to educate.

\section{Conclusion}

The positive role of teachers can be seen in the attitude of fostering religious awareness and multicultural attitudes at Cirebon 2 State High School by providing religious lessons. The teacher teaches multicultural values because it has students from various religions and cultures. Teachers and students are the spearhead of multicultural education development. Teachers determine success and encourage crosscultural understanding in learners. What is conveyed, teaching methods, and the personality of the teacher greatly affect the success of learning.

The strategy of Islamic religious education teachers in growing religious multiculturalism through sustainable character education learning. With the aim that students become individuals with an Islamic spirit who have traits, characters and behaviors that are based on Islamic values. With the aim that students become individuals with an Islamic spirit who have the nature, character and behavior based on the values of Islamic teachings. Therefore, it is necessary to play the role of Islamic Religious Education teachers in growing religious multicultural education. Teachers play an active role in fostering religious multiculturalism for students because it is related to one's personality in understanding diversity and mutual respect for differences in religion, ethnicity, language and social status.

There are several obstacles faced by some teachers of Islamic religious education in growing multicultural education in the school environment. The first is religious fanaticism, the difficulty in directing and controlling fanatical students. Second, the teacher cannot control the application of daily interactions. Third, the level of awareness of students is different to be an obstacle faced in growing multicultural education in the school environment. Educating by example becomes an important factor in shaping the good and bad of students.

\section{Reference}

Akob, B. (2016). The Development of Multicultural Discourse in the Historical Learning: A Case Study on Samudra University Langsa Aceh. International Journal of Multicultural and Multireligious Understanding, 3(5), 1-8.

Burhani, Y., Jinan, G. Y., Saepulloh, M. I., \& Islam, R. C. (2020). Pendidikan Multikulturalisme Gus Dur. Jaqfi: Jurnal Aqidah Dan Filsafat Islam, 5(2), 237-250.

Carlan, Sumarna, C., Djubaedi, D., Fatimah, S., Mas'ud, A., Jamali, Nurul Rosidin, D., \& Hidayat, A. (2021). Multicultural Value of Education in Forming the Community's Religious Attitude. International Journal of Recent Advances in Multidisciplinary Topics, 2(8 SE-Articles), 168-171. https://journals.resaim.com/ijramt/article/view/1303

Chrobot-Mason, D., \& Leslie, J. B. (2012). The role of multicultural competence and emotional intelligence in managing diversity. The Psychologist-Manager Journal, 15(4), 219-236. https://doi.org/10.1080/10887156.2012.730442

Cunningham, D. J. (2005). Teaching multiculturalism in an age of terrorism: a business perspective. Cross Cultural Management: An International Journal, 12(2), 51-68. https://doi.org/10.1108/13527600510798015

De Ricco, J. N., \& Sciarra, D. T. (2005). The immersion experience in multicultural counselor training: Confronting covert racism. Journal of Multicultural Counseling and Development, 33(1), 2-16.

Juwono, S., Aryanti, D., \& Maria, K. (2017). Caruban sebagai Asal Nama "Cirebon" Eksplorasi Spirit Arsitektur. Prosiding Seminar Heritage IPLBI, 100, 69. 
Mathison, C. (1999). How Teachers Feel about Character Education: A Descriptive Study. Action in Teacher Education, 20(4), 29-38. https://doi.org/10.1080/01626620.1999.10462932

Miskan, M. (2018). Pemikiran Multikulturalisme KH Abdurrahman Wahid (Gus Dur) dan Implikasinya terhadap Pendidikan Agama Islam di Indonesia. AL-FURQAN, 6(2), 34-57.

Modood, T. (2009). In Defence of Multicultural Citizenship. In What is Radical Politics Today? (pp. 153161). Palgrave Macmillan UK. https://doi.org/10.1057/9780230251144_18

Naim, N. (2017). Pendidikan multikultural, konsep dan aplikasi (Vol. 1). Ar-Ruzz Media.

Ochieng, E. G., \& Price, A. D. F. (2010). Managing cross-cultural communication in multicultural construction project teams: The case of Kenya and UK. International Journal of Project Management, 28(5), 449-460. https://doi.org/10.1016/j.ijproman.2009.08.001

Pratama, S. Y., Nurkamto, J., \& Wijayanto, A. (2021). The Representation of Multicultural Values in National Mandatory English Textbooks Used in Indonesian Secondary Schools. International Journal of Multicultural and Multireligious Understanding, $8(1), \quad 472$. https://doi.org/10.18415/ijmmu.v8i1.2337

Setiawan, E. (2017). Pemikiran Abdurrahman Wahid tentang Prinsip Pendidikan Islam Multikultural Berwawasan Keindonesiaan. Jurnal Pendidikan Islam, 2(1), 1-14.

Shohib, M. (2020). Substansi Pendidikan Multikultural Perspektif Gus Dur. EDURELIGIA: Jurnal Pendidikan Agama Islam, 4(1), 75-87.

Usman, S., Qodir, Z., \& Hasse, J. (2014). Radikalisme agama di Indonesia. Yogyakarta: Pustaka Pelajar.

Y1lmaz, F. (2016). Multiculturalism and multicultural education: A case study of teacher candidates' perceptions. Cogent Education, 3(1), 1172394. https://doi.org/10.1080/2331186X.2016.1172394

\section{Copyrights}

Copyright for this article is retained by the author(s), with first publication rights granted to the journal.

This is an open-access article distributed under the terms and conditions of the Creative Commons Attribution license (http://creativecommons.org/licenses/by/4.0/). 